\title{
MERCURY POLLUTION ASSESSMENT OF MINING WASTES AND SOILS FROM FORMER SILVER AMALGAMATION AREA IN NORTH-CENTRAL MEXICO
}

\author{
Adriana Karina LEURA VICENCIO ${ }^{1}$, Leticia CARRIZALES YAÑEZ ${ }^{2}$ and Israel RAZO SOTO ${ }^{3 *}$
}

\footnotetext{
${ }^{1}$ Programas Multidisciplinarios de Posgrado en Ciencias Ambientales, Universidad Autónoma de San Luis Potosí. Doctor Manuel Nava 201, Zona Universitaria, San Luis Potosí, San Luis Potosí, México, C. P. 78290

${ }^{2}$ Coordinación para la Innovación y Aplicación de la Ciencia y la Tecnología, Centro de Investigación Aplicada en Ambiente y Salud. Universidad Autónoma de San Luis Potosí. Sierra Leona 550, Lomas 2a. Sección, San Luis Potosí, San Luis Potosí, México, C. P. 78210

${ }^{3}$ Facultad de Ingeniería, Universidad Autónoma de San Luis Potosí. Doctor Manuel Nava 8, Zona Universitaria, San Luis Potosí, San Luis Potosí, México, C. P. 78290

*Corresponding author: israel.razo.soto@gmail.com
}

(Received June 2016; accepted March 2017)

Key words: patio process, tailings, reprocessing, solubility, bioaccessibility

\begin{abstract}
Mining wastes and soils from Cedral, San Luis Potosí, Mexico, were studied to assess mercury $(\mathrm{Hg})$ pollution in areas of historical silver $(\mathrm{Ag})$ amalgamation and in areas where amalgamation mining wastes were recently reprocessed for $\mathrm{Hg}$ and $\mathrm{Ag}$ recovery. The total, soluble and bioaccessible $\mathrm{Hg}$ concentrations from eight mining waste and nine soil cores were determined at varying depths, which fluctuated from the surface up to $1.0 \mathrm{~m}$ depth. The total $\mathrm{Hg}$ concentrations in the mining wastes samples ranged from 8 to $548 \mathrm{mg} / \mathrm{kg}$. The total $\mathrm{Hg}$ concentrations in the soil samples were lower (1 to $116 \mathrm{mg} / \mathrm{kg}$ ) than those in the mining wastes. Eighty percent of the soil samples exceeded the maximum permissible limit for residential soils according to the Mexican regulations, demonstrating the impacts of the amalgamation process in Cedral. The soluble $\mathrm{Hg}$ concentrations were low, from 0.009 to $0.32 \mathrm{mg} / \mathrm{kg}$ in the mining wastes, and from 0.003 to $0.02 \mathrm{mg} / \mathrm{kg}$ in soils. The latter represents $0.007 \%$ to $0.54 \%$ and $<$ $0.03 \%$ of total $\mathrm{Hg}$, from mining wastes and soils, respectively, indicating low aqueous $\mathrm{Hg}$ transport during rainfall events. The bioaccessible $\mathrm{Hg}$ concentrations in the mining waste samples $(0.1$ to $60 \mathrm{mg} / \mathrm{kg})$ and soil samples $(0.1$ to $17 \mathrm{mg} / \mathrm{kg})$, suggested that humans could be exposed to this toxic element through the accidental ingestion of mining wastes and soil particles. Although the total $\mathrm{Hg}$ concentrations in the mining wastes decreased after reprocessing, the soluble and bioaccessible $\mathrm{Hg}$ concentrations increased.
\end{abstract}

Palabras clave: beneficio de patio, jales, reprocesamiento, solubilidad, bioaccesibilidad

\section{RESUMEN}

Se estudiaron residuos mineros y suelos de Cedral, San Luis Potosí, México, para evaluar la contaminación por mercurio $(\mathrm{Hg})$ en áreas de amalgamación histórica de plata (Ag) y de reprocesamiento reciente de residuos de amalgamación para la recuperación de Hg y Ag. Se obtuvieron ocho perfiles de hasta $1 \mathrm{~m}$ de profundidad de depósitos de 
residuos mineros y nueve de suelo, de los cuales se recolectaron muestras a diferentes profundidades para la determinación de concentraciones totales, solubles y bioaccesibles de $\mathrm{Hg}$. Las concentraciones totales de $\mathrm{Hg}$ en residuos mineros variaron entre 8 y $548 \mathrm{mg} / \mathrm{kg}$, mientras que en suelos las concentraciones se presentaron en un rango de entre 1 y $116 \mathrm{mg} / \mathrm{kg}$. Se encontró que el $80 \%$ de las muestras de suelo analizadas superaron el límite máximo permisible de $\mathrm{Hg}$ para suelo de uso residencial establecido en la normatividad mexicana, lo que demuestra el severo impacto de la amalgamación y del reprocesamiento de jales de amalgamación en Cedral. Con relación a las concentraciones solubles de $\mathrm{Hg}$, en las muestras de residuos se obtuvieron de 0.009 a 0.32 $\mathrm{mg} / \mathrm{kg}$ y de 0.003 a $0.02 \mathrm{mg} / \mathrm{kg}$ para suelos, lo que representa de $0.007 \%$ a $0.54 \%$ $\mathrm{y}<0.03 \%$ del total de $\mathrm{Hg}$ contenido en residuos mineros y suelos, respectivamente. Esto indica un bajo potencial de transporte de especies solubles de $\mathrm{Hg}$ durante eventos de lluvia. Finalmente, las concentraciones de $\mathrm{Hg}$ bioaccesible obtenidas en el estudio ( 0.1 a $60 \mathrm{mg} / \mathrm{kg}$ en residuos, 0.1 a $17 \mathrm{mg} / \mathrm{kg}$ en suelos), sugieren una exposición de la población humana a este elemento tóxico a través de la ingestión accidental de partículas de residuos mineros y de suelo. Además, quedó evidenciado que el reprocesamiento de residuos de amalgamación disminuyó las concentraciones totales de $\mathrm{Hg}$, pero incrementó las concentraciones solubles y bioaccesibles de $\mathrm{Hg}$.

\section{INTRODUCTION}

Mercury (Hg) occurs naturally in the Earth's crust and soils, with average concentrations typically not exceeding $0.07 \mathrm{mg} / \mathrm{kg}$ and $1.1 \mathrm{mg} / \mathrm{kg}$, respectively (Kabata-Pendias 2011). However, human activities, including the production of $\mathrm{Hg}$ by mining or recycling activities, the use and production of products containing $\mathrm{Hg}$, fossil fuel combustion, and the uncontrolled disposal of $\mathrm{Hg}$-containing mining wastes, have increased environmental $\mathrm{Hg}$ concentrations sufficiently to result in its classification as a priority global contaminant. Hg is toxic and exhibits exceptional environmental behaviors, including transportation in the atmosphere and its transformation to highly bioavailable chemical forms that bioaccumulate once they enter the food chain (Ebinghaus 1999).

$\mathrm{Hg}$ has been used since ancient times. The first use of $\mathrm{Hg}$ in a large-scale industrial process consisted of recovering gold $(\mathrm{Au})$ and silver $(\mathrm{Ag})$ from low-grade ores by amalgamation with elemental $\mathrm{Hg}$ (Hylander and Meili 2003). The historical importance of the amalgamation process on the world's demand for $\mathrm{Hg}$ is clear because approximately one-fifth of the total recorded $\mathrm{Hg}$ production of $943172 \mathrm{t}$ before $2012 \mathrm{oc}-$ curred between 1550 and 1900 (Hylander and Meili 2003, CEC 2013). Ag mines consumed most of the $\mathrm{Hg}$ produced between 1550 and $1900(\sim 196000 \mathrm{t})$ in colonial Spanish America (CEC 2013). Therefore, the colonial amalgamation process not only encouraged $\mathrm{Hg}$ production and world trade but also contributed to a global increase in environmental $\mathrm{Hg}$ concentrations. Historically, the amalgamation process resulted in $\mathrm{Hg}$ emissions of between $87750 \mathrm{t}$ and $126000 \mathrm{t}$ to the atmosphere (Nriagu 1994, Camargo 2002). Additionally, a significant fraction of the $\mathrm{Hg}$ used in amalgamation in colonial Spanish America (5\% to $20 \%$ ) was accidentally or deliberately released into soils and water, and was primarily incorporated into mining wastes that were abandoned at the mining sites. Historical amalgamation is also likely responsible for the increased local environmental $\mathrm{Hg}$ concentrations at sites where it was practiced (Camargo 2002).

The fate of $\mathrm{Hg}$ in amalgamation mining wastes at most of the historical Ag mining sites from colonial America remains unknown. In the case of Mexico, it was recently estimated that $73473 \mathrm{t}$ of residual $\mathrm{Hg}$ could be contained in the amalgamation tailings produced from 1556 to 1900 (CEC 2013). Moreover, from 1890 to present, leaching methods without control measures for correctly managing reprocessed tailings were applied to reprocess amalgamation mining wastes and polluted soils to recover $\mathrm{Au}, \mathrm{Ag}$ and $\mathrm{Hg}$ at some historical mining sites in Zacatecas, Guanajuato and San Luis Potosí (Ogura et al. 2003, Ramos-Arroyo et al. 2004, CEC 2013). Therefore, sites where metal amalgamation and the reprocessing of amalgamation tailings were practiced, must be considered as potentially contaminated with $\mathrm{Hg}$.

Although $\mathrm{Hg}$ pollution persists at historical amalgamation sites, elevated $\mathrm{Hg}$ concentrations occur in "hot spots", and the soluble and bioavailable fractions of $\mathrm{Hg}$ at these sites are generally low $(<0.1 \%)$. The latter because the predominant chemical species associated with the residual fraction are most likely 
elemental $\mathrm{Hg}$ and $\mathrm{HgS}$ (Lacerda 1997, Johnson and Whittle 1999, Lang 1999). However, elemental Hg is subjected to chemical transformations, such as oxidation, dissolution, amalgamation, precipitation and adsorption, which affect its chemical speciation during the amalgamation process (Slowey et al. 2005) and its transformations due to chemical weathering or biological activity (Navarro 2008). Moreover, the chemical transformations of $\mathrm{Hg}$ that occur when amalgamation mining wastes are reprocessed remain unknown. However, reprocessing these wastes could result in the chemical transformation of $\mathrm{Hg}$ to more soluble and bioavailable species, which would increase environmental and human health risks. This situation might be the case in Cedral in the state of San Luis Potosí, Mexico, where uncontrolled historical amalgamation tailings were reprocessed and abandoned in the vicinity of urban areas.

Therefore, the aim of this study was to assess the grade of $\mathrm{Hg}$ pollution of non-reprocessed and reprocessed mining wastes, and of soils within and outside of the former Ag amalgamation facilities in Cedral, San Luis Potosí, Mexico. The assessment of $\mathrm{Hg}$ pollution at this site includes the determination of total, soluble and bioaccessible $\mathrm{Hg}$ concentrations by using methods that have been developed for the extraction of contaminants from solid mining wastes and soils to predict potential effects on health and environmental impact. The solubility test used in this study was developed to assess the leaching potential of contaminants from solid mining wastes or soils in contact with simulated meteoric water (ASTM 2004), whereas bioaccessibility infers the fraction of a contaminant dissolved from soils or mining wastes under acidic gastric conditions and could be available for absorption through the gastrointestinal tract (Zagury et al. 2009). Solubility and bioaccessibility of $\mathrm{Hg}$ in mining wastes and soils are mainly controlled by the chemical species (Bloom et al. 2003, Zagury et al. 2009). Thus, the soluble and bioaccessible Hg concentrations, together with the total $\mathrm{Hg}$ concentration, would provide useful complementary information about the chemical speciation of $\mathrm{Hg}$ in mining wastes and soils of Cedral, reported previously by selective extraction methods (Morton-Bermea et al. 2015).

\section{MATERIALS AND METHODS}

\section{Study site}

The study site was located in the city of Cedral in northern San Luis Potosí, Central Mexico, at approximately $23^{\circ} 49^{\prime} \mathrm{N}, 100^{\circ} 43^{\prime} \mathrm{W}$ (Fig. 1). In 2010, the city of Cedral had 11468 inhabitants (INEGI 2010). The climate is dry-temperate, with an annual average of temperature, precipitation and evaporation of $10.6^{\circ} \mathrm{C}, 405.1 \mathrm{~mm}$ and $2090 \mathrm{~mm}$, respectively (SMN 2015). The regional geology consist of continental and marine sedimentary rocks that vary in age from the Middle Jurassic to the Upper Cretaceous, which belong to the Mesozoic Basin of Central Mexico. These geological units are covered indistinctly by continental sediments of the Cenozoic age represented by lacustrine deposits of Paleogene age, polymictic conglomerate of Neogene age, and siltgravel and alluvium of the Quaternary. The igneous geological units are restricted to small basalt outcrops of Miocene age (SGM 2013). The regional soils are derived from sedimentary rocks, and the soils in the urban area of Cedral are predominantly classified as Gypsic Xerosols with overlapping calcrete hardpan or caliche layers of varying depths (INEGI 2009).

During the late 18th century, at least seven metallurgical facilities were installed in the urban area of Cedral to recover $\mathrm{Ag}$ from ores that were mined in the Real de Catorce mining area, $25 \mathrm{~km}$ southwest of Cedral. According to historical maps of the study area (Aguirre 1878), the former metallurgical facilities, called "haciendas de beneficio", were located at the southwest margin of the urban area of Cedral (Fig. 1). At these facilities, the amalgamation method known as "beneficio de patio" was used, which consisted of the following five sequential operations (Bargalló 1969): 1) the ore was crushed using stone mills, 2) the pulverized ore was spread on a large stone pavement court and common salt $(\mathrm{NaCl})$ and magistral (roasted copper and iron sulfides) were added, 3) elemental $\mathrm{Hg}$ was thoroughly mixed with the pulverized ore before allowing the amalgamation reaction to occur for three weeks to five months, depending on the room temperature, 4) the $\mathrm{Ag}-\mathrm{Hg}$ amalgam (pella) was recovered by adding elemental $\mathrm{Hg}$ to increase the fluidity before separating the low-density materials using a stream of water (in this step, major mining wastes and amalgamation tailings were produced and commonly dumped in surrounding areas), and 5) $\mathrm{Hg}$ was separated from the pella by heating in a retort to recover metallic $\mathrm{Ag}$ and some of the $\mathrm{Hg}$ by condensation. The total amount of $\mathrm{Hg}$ used in the amalgamation facilities installed in Cedral, remains unknown but it is estimated that, between 1773 and $1827,5000 \mathrm{t}$ of $\mathrm{Hg}$ were approximately consumed in the Real de Catorce mining region, which includes Cedral (Ávalos-Lozano et al. 2007).

In 1905, only one "hacienda de beneficio" was operating in Cedral (Hornelas 1905). Soon after, 


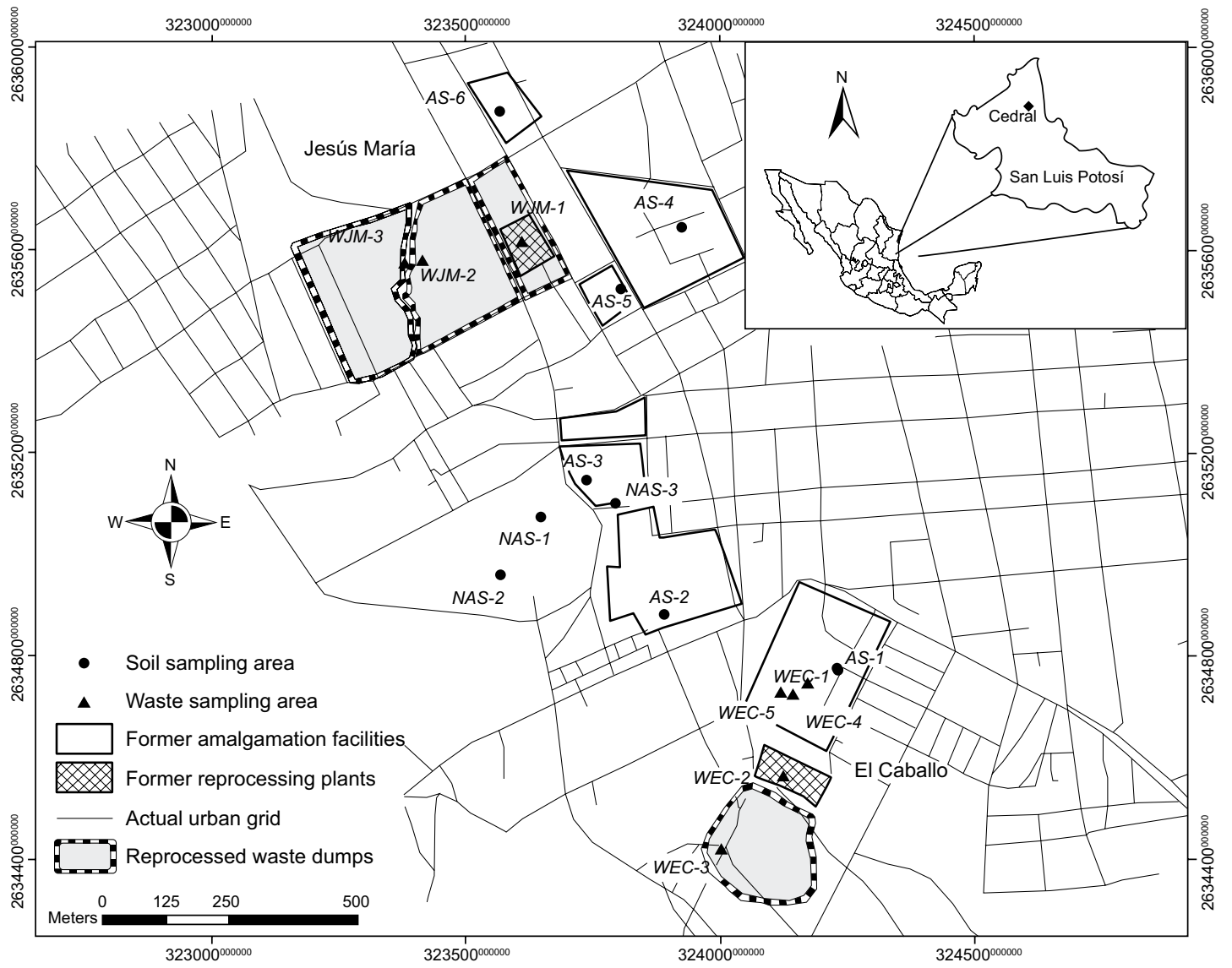

Fig. 1. Location of Cedral, San Luis Potosí, Mexico, and descriptive map of the mining waste sample areas at El Caballo (WEC) and Jesús María (WJM) reprocessing plants, and sample areas of indirectly affected soils (NAS) and directly affected soil (AS) at former amalgamation facilities

the production of Ag by amalgamation was stopped completely. Subsequently, the land occupied by the amalgamation facilities was gradually converted into recreational and residential land.

The amalgamation mining wastes (tailings) were reprocessed to recover $\mathrm{Ag}$ and $\mathrm{Hg}$ at two leaching plants that operated from 1920 to 1980 (Fig. 1). Static lixiviation with calcium thiosulfate $\left(\mathrm{CaS}_{2} \mathrm{O}_{3}\right)$ was the method used to recover $\mathrm{Ag}$ and $\mathrm{Hg}$. Considering the characteristics of the investigated facilities, the same process was most likely used at similar reprocessing plants that operated in Zacatecas, Mexico. In this process, elemental sulfur is burned in a conventional furnace and the exhaust gases are bubbled into a suspension of elemental sulfur and $\mathrm{Ca}(\mathrm{OH})_{2}$ in water with vigorous stirring to produce a $\mathrm{CaS}_{2} \mathrm{O}_{3}$ solution. Next, the amalgamation tailings are dumped into leaching ponds where the tailings are lixiviated with the $\mathrm{CaS}_{2} \mathrm{O}_{3}$ solution. The $\mathrm{Ag}$-Hg-rich solution is pumped to a tank for precipitation using copper scrap. Finally, the precipitate is heated in a retort to recover the metallic Ag and $\mathrm{Hg}$ (Ogura et al. 2003, CEC 2013).

The reprocessed amalgamation tailings were dumped near the facilities, which were abandoned after the closure of the reprocessing plants in Cedral. Therefore, within the urban area of Cedral, two primary reprocessed tailing dumpsites exist: El Caballo and Jesús María (Fig. 1).

\section{Sampling and sample preparation}

Seventeen sample areas were selected based on the locations of former amalgamation facilities according to historical maps from Cedral (Aguirre 1878, Hornelas 1905) and on the locations of abandoned leaching plants and reprocessed mining wastes dumps. Eight areas were selected for soils sampling (Table I), including three near former amalgamation facilities to represent soils that were affected indirectly by the amalgamation 
TABLE I. DESCRIPTION OF SELECTED AREAS FOR INDIRECTLY AFFECTED SOIL (NAS) AND DIRECTLY AFFECTED SOIL (AS) SAMPLINGS

\begin{tabular}{lc}
\hline Sample area & Description \\
\hline NAS-1 & $\begin{array}{c}\text { Indirectly affected soil outside former } \\
\text { amalgamation facilities } \\
\text { NAS-2 }\end{array}$ \\
NAS-3 & $\begin{array}{c}\text { Indirectly affected soil outside former } \\
\text { amalgamation facilities } \\
\text { Indirectly affected soil outside former } \\
\text { amalgamation facilities } \\
\text { AS-1 }\end{array}$ \\
AS-2 & $\begin{array}{c}\text { Directly affected soil within a former } \\
\text { amalgamation facility }\end{array}$ \\
AS-3 & $\begin{array}{c}\text { Directly affected soil within a former } \\
\text { amalgamation facility } \\
\text { amalgamation facility }\end{array}$ \\
AS-4 & $\begin{array}{c}\text { Directly affected soil within a former } \\
\text { amalgamation facility }\end{array}$ \\
AS-5 & $\begin{array}{c}\text { Directly affected soil within a former } \\
\text { amalgamation facility }\end{array}$ \\
\hline
\end{tabular}

process (NAS-1 to NAS-3), and six inside former amalgamation facilities to represent soils that were affected directly by amalgamation (AS-1 to AS-6). In addition, five areas were selected at the mining wastes dumps at El Caballo (WEC-1 to WEC-5), and three at the Jesús María (WJM-1 to WJM-3) reprocessing site (Table II). Additionally, one area with low anthropogenic influence was used as a reference site. In figure 1, the locations of the sample areas are shown, except the reference sample area, which was located approximately $1.5 \mathrm{~km}$ southeast from the El Caballo site.

In each sample area, three soils or mining waste cores were obtained using a Pürckhauer sampler within a $1 \mathrm{~m}^{2}$ area. The depths of the soils and mining waste cores fluctuated from the surface to $1.0 \mathrm{~m}$, and each core was divided into sections measuring approximately $10 \mathrm{~cm}$ or more depending on the color and the texture of the material. Thus, 48 soils and 60 mining wastes samples were obtained, and each sample consisted of a composite of three sections from the same depth of three different soils or mining waste cores. The samples were stored and transported in sealed plastic bags before airdrying at room temperature and passing through a stainless steel ASTM No. $10(<2 \mathrm{~mm})$ mesh sieve.

Four additional cores were collected at WEC-1, WEC-2, WEC-3 and AS-2 and they were not sectioned. These cores were used for bulk characterization of the mining wastes and soils, and are identified in the text as WEC-1B, WEC-2B, WEC-3B and AS-2B.

\section{Mining wastes and soils characterization}

In samples WEC-1B, WEC-2B, WEC-3B and $\mathrm{AS}-2 \mathrm{~B}$, the $\mathrm{pH}$ and the electrical conductivity (EC) were analyzed potentiometrically using an YSI Pro Plus multi-parameter in waste or soil suspension, prepared by mixing thoroughly solid samples with deionized water (1:1 ratio) for $10 \mathrm{~min}$ and let stand for $30 \mathrm{~min}$. The organic matter (OM) content was determined by dichromate oxidation by the WalkleyBlack method (Pansu and Gautheyrou 2006). In addition, the principal mineral phases were identified using X-ray diffraction analysis in a Rigaku D/ max 220 diffractometer $(\lambda=1.5406 \kappa \alpha \mathrm{Cu})$.

\section{Analysis of total $\mathrm{Hg}$ in mining waste and soil samples}

To determine the total $\mathrm{Hg}$ concentrations, the EPA method 3051A(USEPA 2007a) was used for the microwave-assisted acid digestion of $0.5 \mathrm{~g}$ of the soil or mining waste samples and was modified by using $20 \mathrm{~mL}$ of $\mathrm{HNO}_{3} 25 \%-\mathrm{HCl} 10 \%$ as an extraction solution. Acid digestion was conducted in an MDS2000 CEM microwave.

After sample digestion, total $\mathrm{Hg}$ concentrations were determined by atomic absorption spectrometry

TABLE II. DESCRIPTION OF SELECTED AREAS FOR MINING WASTES SAMPLING AT EL CABALLO (WEC) AND JESUS MARIA (WJM) REPROCESSING PLANTS

\begin{tabular}{lll}
\hline Sample area & Reprocessing plant & Description \\
\hline WEC-1 & El Caballo & Non-reprocessed tailings \\
WEC-2 & El Caballo & Reprocessed tailings from a leaching pond \\
WEC-3 & El Caballo & Reprocessed tailings from waste dump top \\
WEC-4 & El Caballo & Non-reprocessed tailings \\
WEC-5 & El Caballo & Non-reprocessed tailings \\
WJM-1 & Jesús María & Reprocessed tailings from a leaching pond \\
WJM-2 & Jesús María & Reprocessed tailings from waste dump top \\
WJM-3 & Jesús María & Reprocessed tailings from waste dump toe \\
\hline
\end{tabular}


with the cold-vapor method (CV-AAS) in an Analyst 100 Perkin-Elmer spectrophotometer at $253.7 \mathrm{~nm}$. The reductant solution used was $\mathrm{NaBH}_{4}$ $0.2 \%$ - NaOH $0.05 \%$ through a flow-injected FIAS 100 Perkin-Elmer system. Before analysis, a drop of $\mathrm{KMnO}_{4} 5 \%$ solution was added to the extract aliquot to maintain an oxidizing medium.

The detection limit for $\mathrm{Hg}$ in the liquid phase was $0.2 \mu \mathrm{g} / \mathrm{L}$, and with the 1:40 solid to solution ratio used in the acid digestion of solid samples, the lowest detectable total concentration of $\mathrm{Hg}$ in the soils and mining waste samples was $0.008 \mathrm{mg} / \mathrm{kg}$. For quality assurance, blanks of a standard reference material (SRM) (2710a "Montana Soil" obtained from the National Institute of Science and Technology, USA) and duplicates were analyzed for all samples. The recovery of $\mathrm{Hg}$ based on the analysis of ten SRM samples ranged from $87 \%$ to $103 \%$.

\section{Determination of soluble $\mathrm{Hg}$ in mining waste and soil samples}

To assess the Hg solubility, five soils and eight mining waste sample areas, accounting for a total of 78 samples, were selected depending on the changes in their total $\mathrm{Hg}$ concentrations with depth. Because of the available sample quantities, it was sometimes necessary to pool contiguous samples.

The soluble $\mathrm{Hg}$ obtained from the selected soils and mining waste samples was determined using the D-3987-85 method from ASTM (2004), which was consistent with the official Mexican guidelines for the characterization of metal-contaminated soils and mining wastes (SEMARNAT 2004, 2009). The procedure used to determine soluble $\mathrm{Hg}$ employed deionized water that was adjusted to $\mathrm{pH} 5.5 \pm 0.1$ by $\mathrm{CO}_{2}$ addition to simulate the leachability of the solids in contact with meteoric water (ASTM 2004). Two grams of each solid sample (soils or mining wastes) were extracted in a $40 \mathrm{~mL}$ of solution for $18 \pm 0.25 \mathrm{~h}$ in $50 \mathrm{~mL}$ high-density polyethylene (HDPE) vials at room temperature using a rotatory agitator at $30 \mathrm{rpm}$. After extraction, the samples were centrifuged for $20 \mathrm{~min}$ at $3000 \mathrm{rpm}$ and the supernatant solutions were vacuum-filtered through disposable $0.45-\mu \mathrm{m}$ nitrocellulose filters. The filtrated leachates were preserved by adding two drops of $\mathrm{HNO}_{3} 25 \%$ solution and were stored at $4^{\circ} \mathrm{C}$ until the $\mathrm{Hg}$ analysis with CV-AAS was performed. Considering the 1:20 solid-to-solution ratio established in the extraction procedure for soluble $\mathrm{Hg}$ determinations and the detection limit of the $\mathrm{Hg}$ analysis method $(0.2 \mu \mathrm{g} / \mathrm{L})$, the lowest soluble $\mathrm{Hg}$ concentration that could be reliably detected in the soils and mining waste samples was $0.004 \mathrm{mg} / \mathrm{kg}$.

\section{Determination of bioaccessible $\mathrm{Hg}$ in mining waste and soil samples}

The same soils and mining waste samples that were selected for the solubility assessment were used to evaluate $\mathrm{Hg}$ bioaccessibility. The bioaccessibility of $\mathrm{Hg}$ was determined using an in vitro method that was established to measure the fraction of a chemical solubilized from a solid sample under the simulated acidic conditions of the mammalian gastrointestinal tract (Kelley et al. 2002).

For the bioaccessibility assessment, $1.0 \pm 0.05 \mathrm{~g}$ of the mining wastes or soils sample was extracted in $100 \mathrm{~mL}$ of a simulated stomach acid solution, which consisted of a $0.4 \mathrm{M}$ glycine solution at $37^{\circ} \mathrm{C}$ that was adjusted to $\mathrm{pH} 1.5 \pm 0.05$ using $\mathrm{HCl}$. The samples were mixed at $30 \mathrm{rpm}$ in a rotatory agitator for $1 \mathrm{~h}$ in $125 \mathrm{~mL}$ HDPE bottles at $37 \pm 2{ }^{\circ} \mathrm{C}$. After extraction, the samples were centrifuged for $20 \mathrm{~min}$ at $3000 \mathrm{rpm}$, and the supernatant solutions were vacuum-filtered through disposable $0.45-\mu \mathrm{m}$ nitrocellulose filters. The filtrates were preserved by adding two drops of a $\mathrm{HNO}_{3} 25 \%$ solution and were stored at $4{ }^{\circ} \mathrm{C}$ until $\mathrm{Hg}$ analysis by $\mathrm{CV}-\mathrm{AAS}$. For quality control, $10 \mathrm{SRM}$ (2711 "Montana Soil") samples were analyzed. The concentration of lead $(\mathrm{Pb})$ extracted from the SRM ranged from 8.7 to $10.3 \mathrm{mg} / \mathrm{L}$, which confirmed the accurate performance of the extraction method (USEPA 2007b). Based on the 1:100 solid to solution ratio used in the extraction procedure and the detection limit of the $\mathrm{Hg}$ analysis method $(0.2 \mu \mathrm{g} / \mathrm{L})$, the lowest bioaccessible $\mathrm{Hg}$ concentration that could be reliably detected in soils or mining waste samples was $0.02 \mathrm{mg} / \mathrm{kg}$.

\section{Data analysis}

Statistical analyses were performed using SigmaPlot (v11.0, Systat Software Inc.). One-way ANOVA (with a $95 \%$ confidence interval) was used to determine whether the total, soluble or bioaccessible concentrations of $\mathrm{Hg}$ in the soils and mining waste samples differed with depth. For statistical analysis, the resulting data were grouped based on the three following depths: 0-30 cm, 30-60 cm and $60-100 \mathrm{~cm}$.

\section{RESULTS AND DISCUSSION}

\section{Mining waste and soil characterization}

The results from the bulk characterization of the mining waste and soil cores are summarized in table III. No differences were observed in the $\mathrm{pH}$ values between the mining waste and the soil samples. In addition, reprocessing the amalgamation mining 
TABLE III. BULK CHARACTERIZATION OF SAMPLES FROM EL CABALLO WASTES (WEC) AND DIRECTLY AFFECTED SOIL SAMPLES (AS)

\begin{tabular}{|c|c|c|c|c|c|c|c|}
\hline \multirow[t]{2}{*}{ Sample } & \multirow[t]{2}{*}{ Description } & \multirow[t]{2}{*}{$\mathrm{pH}$} & \multirow{2}{*}{$\begin{array}{c}\text { Electrical } \\
\text { conductivity } \\
(\mu \mathrm{S} / \mathrm{cm})\end{array}$} & \multirow{2}{*}{$\begin{array}{l}\text { Organic } \\
\text { matter } \\
(\%)\end{array}$} & \multicolumn{3}{|c|}{$\begin{array}{l}\text { Major }(+++) \text {, middle }(++) \text { and } \\
\text { minor }(+) \text { mineral phases }\end{array}$} \\
\hline & & & & & $\mathrm{SiO}_{2}$ & $\mathrm{CaCO}_{3}$ & $\mathrm{CaSO}_{4} \cdot 2 \mathrm{H}_{2} \mathrm{O}$ \\
\hline WEC-1B & Non-processed waste & 7.9 & 1381 & 3.6 & +++ & + & ++ \\
\hline WEC-2B & Reprocessed waste from leaching pond & 8.2 & 3113 & 0.4 & +++ & ++ & + \\
\hline WEC-3B & Reprocessed waste & 7.8 & 4968 & 3.0 & +++ & ++ & + \\
\hline AS-2B & Directly affected soil & 7.6 & 2609 & 6.9 & + & ++ & +++ \\
\hline
\end{tabular}

wastes increased the EC of the mining waste samples. The relatively high EC value in AS-2B could be associated with the predominating soil type in Cedral, which corresponds to gypsic soils with more than $15 \%$ saturated sodium within a depth of $125 \mathrm{~cm}$ (INEGI 1972). Thus, it is very likely that the EC in other soil samples is also relatively high. The mining waste samples had relatively high organic matter contents, particularly samples WEC-1B and WEC-3B, due to the presence of vegetation patches in the sampling areas. However, the organic matter contents in the mining waste samples were lower than that found in soil sample AS-2B.

The main components of the amalgamation mining waste sample (WEC-1B) that were observed by $\mathrm{X}$-ray diffraction analyses were quartz $\left(\mathrm{SiO}_{2}\right)$, gypsum $\left(\mathrm{CaSO}_{4} \cdot 2 \mathrm{H}_{2} \mathrm{O}\right)$ and calcite $\left(\mathrm{CaCO}_{3}\right)$ (in decreasing order of abundance). When analyzing the reprocessed mining wastes sampled at the leaching pond (WEC-2B) and at the reprocessed mining waste dump (WEC-3B), the same main minerals were identified, but calcite was more abundant than gypsum. These results agree with the mineralogical composition of the Au-Ag ore amalgamated in $\mathrm{Ce}$ dral, where quartz and calcite represented the main gangue minerals for the deposits mined in Real de Catorce (CRM 1992). The relative abundance of gypsum in WEC-1B indicates that this sample consisted of a mixture of un-reprocessed mining wastes and soils because gypsum is mainly associated with the natural composition of the gypsic soils at the site, as shown by sample AS-2B.

\section{Total $\mathrm{Hg}$ concentrations in the mining wastes and soils}

The concentrations of $\mathrm{Hg}$ in the mining waste samples from the study area ranged from 8 to $548 \mathrm{mg} / \mathrm{kg}$. These concentrations were similar to those from studies conducted worldwide, with residual $\mathrm{Hg}$ concentrations in the historical amalgamation tailings ranging from $<0.5$ to $4900 \mathrm{mg} / \mathrm{kg}$ (Lacerda and
Salomons 1999). In addition, these concentrations were similar to those found in amalgamation tailings at other historical mining sites in Zacatecas, with $\mathrm{Hg}$ concentrations ranging from $<0.08$ to $264 \mathrm{mg} / \mathrm{kg}$ (Ogura et al. 2003). In most of these cases, the identification of "hot spots" with high $\mathrm{Hg}$ concentrations indicated that the mining wastes were potential longlasting sources of contamination (Lacerda and Salomons 1999). This outcome likely occurred in Cedral because $\mathrm{Hg}$ levels as high as $548 \mathrm{mg} / \mathrm{kg}$ occurred in uncontrolled mining waste dumps; to our knowledge, this is the highest $\mathrm{Hg}$ concentration reported for this type of $\mathrm{Hg}$ source in Mexico.

Notable differences were observed in the variation of the $\mathrm{Hg}$ concentrations among the mining waste sampling areas (Fig. 2). According to the different characteristics among the mining waste sample sites (Table II), the differences in the total Hg concentrations were associated with $\mathrm{Hg}$ extraction during reprocessing. Therefore, a negative gradient of the $\mathrm{Hg}$ concentrations is observed from the not reprocessed tailings (WEC-1, 276 to $584 \mathrm{mg} / \mathrm{kg}$ ), to the lixiviation pond of the reprocessing plant (WEC-2, 148 to 484 $\mathrm{mg} / \mathrm{kg}$ ), and to the reprocessed wastes (WEC-3, 18 to $36 \mathrm{mg} / \mathrm{kg}$ ). Similar low $\mathrm{Hg}$ concentrations were observed in sample areas WJM-1 to WJM-3 from Jesús María dump (Fig. 2B). According to Ogura et al. (2003), the efficiency of the lixiviation method for reprocessing amalgamation tailings, as used in Cedral, could reach a $\mathrm{Hg}$ extraction efficiency of up to $72 \%$. Thus, a significant fraction of $\mathrm{Hg}$ persisted in the mining wastes even after reprocessing, as shown by the El Caballo (WEC-3) and Jesús María (WJM-1 to WJM-3) reprocessed mining waste samples.

The total mean $\mathrm{Hg}$ concentrations did not significantly differ (ANOVA, $95 \%$ CI) with depth when considering depths of $0-30 \mathrm{~cm}(112 \pm 33 \mathrm{mg} / \mathrm{kg})$, $30-60 \mathrm{~cm}(157 \pm 21 \mathrm{mg} / \mathrm{kg})$ and $60-100 \mathrm{~cm}(130 \pm$ $85 \mathrm{mg} / \mathrm{kg}$ ). However, the $\mathrm{Hg}$ concentration profiles were different among the sample areas (Fig. 2A, 2B). The sample areas with lower $\mathrm{Hg}$ concentrations 

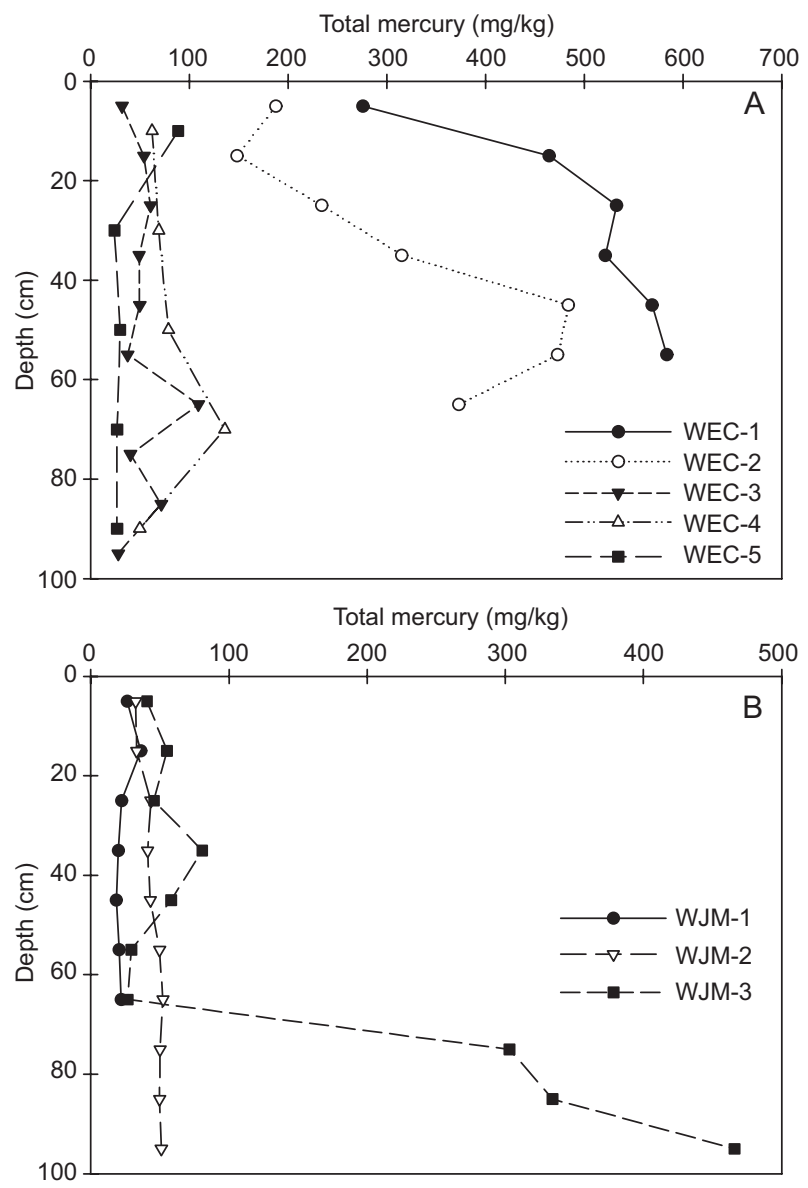

Fig. 2. Variations in the total mercury concentrations $(\mathrm{mg} / \mathrm{kg})$ with depth $(\mathrm{cm})$ at the mining wastes sample areas. (A) El Caballo wastes (WEC), (B) Jesús María wastes (WJM)

(WEC-3 to WEC-5 and WJM-1 to WJM-3) showed little variation in the $\mathrm{Hg}$ concentrations with depth, and the concentrations ranged from 18 to $90 \mathrm{mg} / \mathrm{kg}$, except for WEC-3 and WEC-4, which had noticeable $\mathrm{Hg}$ concentration peaks at depths of $60-70 \mathrm{~cm}$ $(109 \mathrm{mg} / \mathrm{kg})$ and $60-80 \mathrm{~cm}(136 \mathrm{mg} / \mathrm{kg})$, respectively. Additionally, the WJM-3 sample area showed a significant increase in the $\mathrm{Hg}$ concentration from $27 \mathrm{mg} / \mathrm{kg}$ in the $60-70 \mathrm{~cm}$ section to $303 \mathrm{mg} / \mathrm{kg}$ in the $70-80 \mathrm{~cm}$ section, $334 \mathrm{mg} / \mathrm{kg}$ in the $80-90 \mathrm{~cm}$ section, and $466 \mathrm{mg} / \mathrm{kg}$ in the $90-00 \mathrm{~cm}$ section. The relative uniformity of the $\mathrm{Hg}$ concentrations could be explained by the homogenization of mining wastes due to stockpiling and reprocessing the amalgamation tailings. The anomalous $\mathrm{Hg}$ concentrations in the deepest sections of WJM-3 could be related to the specific conditions of the sample area because the WJM-3 samples were obtained at the toe of the Jesús María tailing dump. In contrast, the WJM-2 sample area (maximum $\mathrm{Hg}$ concentration of $52 \mathrm{mg} / \mathrm{kg}$ ), was obtained at the top of the same mining waste dump.

For sample areas WEC-1 and WEC-2, the $\mathrm{Hg}$ concentration clearly increased with depth from 276 and $187 \mathrm{mg} / \mathrm{kg}$ in the first $10 \mathrm{~cm}$ to $584 \mathrm{mg} / \mathrm{kg}$ at $50-$ $60 \mathrm{~cm}$, and to $484 \mathrm{mg} / \mathrm{kg}$ at $40-50 \mathrm{~cm}$, respectively. $\mathrm{The} \mathrm{Hg}$ levels remained high in the deeper layers at WEC-1 and decreased in WEC-2. The lower levels of $\mathrm{Hg}$ in the surface sections from WEC-1 and WEC-2 potentially resulted from the release of elemental $\mathrm{Hg}$ vapor, particularly because amalgamation tailings were proposed to be an important source of atmospheric $\mathrm{Hg}$ emissions due to the presence of elemental $\mathrm{Hg}$ (Lacerda 1997). The Hg degassing rates depend on multiple climatic factors, such as temperature, solar radiation and rainfall events (Song and Van Heyst 2005, Moore and Castro 2012). Therefore, the semiarid conditions at the study site potentially promoted the release of $\mathrm{Hg}$ from the surfaces of the mining waste dumps (Navarro 2008).

Figure 3 shows the total $\mathrm{Hg}$ concentrations in soils at the Cedral sampling sites, which ranged from 1.0 $\mathrm{mg} / \mathrm{kg}$ to $116 \mathrm{mg} / \mathrm{kg}$ and were lower than the concentrations observed in the mining waste sample areas. The observed $\mathrm{Hg}$ concentrations generally confirmed that metallurgical activities affected the soils because the $\mathrm{Hg}$ concentrations were higher than the regional background $\mathrm{Hg}$ concentrations, which ranged from 0.39 to $0.83 \mathrm{mg} / \mathrm{kg}$, as previously reported for Cedral (Chiprés et al. 2008). Moreover, the $\mathrm{Hg}$ concentrations at the reference site were $9 \mathrm{mg} / \mathrm{kg}$ at $0-10 \mathrm{~cm}$ and $17 \mathrm{mg} / \mathrm{kg}$ at $10-20 \mathrm{~cm}$, indicating that anthropogenic influence likely occurred at the soil surface. However, no anthropogenic influence was evident in the deeper sections where the $\mathrm{Hg}$ concentrations remained below the detection limit $(<0.008 \mathrm{mg} / \mathrm{kg})$. Therefore, the results from the reference area indicate that past and distant $\mathrm{Hg}$ sources influenced the soil surface and that the $\mathrm{Hg}$ concentrations throughout the soil profile were consistent with surface deposition (Santos-Francés et al. 2011). In contrast with the soils at the reference site, the surface and deep soil samples from the study area had higher $\mathrm{Hg}$ concentrations, with $80 \%$ of the soil samples exceeding the maximum permissible limit of $23 \mathrm{mg} / \mathrm{kg}$ for residential soils according to Mexican regulations (SEMARNAT 2004) and the USEPA (2014).

These results demonstrate severe $\mathrm{Hg}$ pollution in soils as a consequence of past metallurgical and recent reprocessing activities in the study area. Notably, the $\mathrm{Hg}$ concentrations in the deeper sections from the NAS-2, AS-1, AS-2 and AS-3 sample areas were higher than the levels allowed by Mexican 

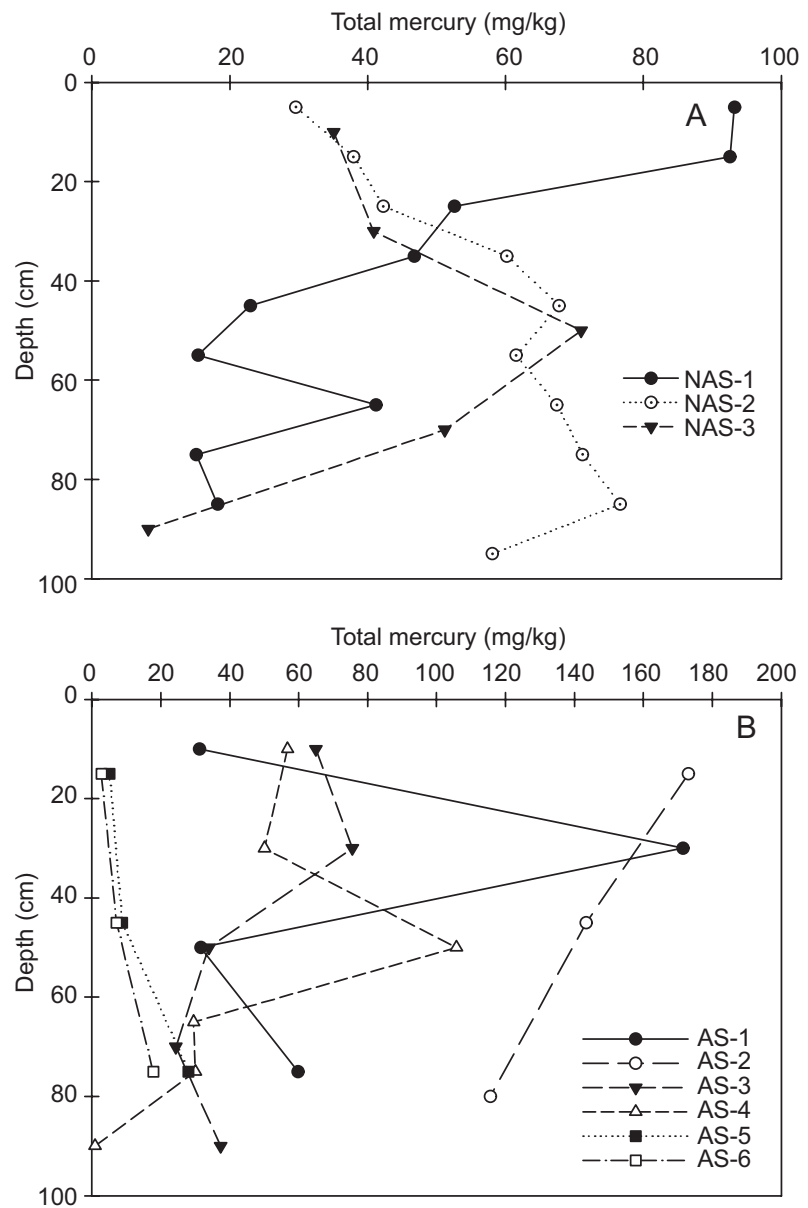

Fig. 3. Variations in the total mercury concentrations $(\mathrm{mg} / \mathrm{kg})$ with depth $(\mathrm{cm})$ at the soil sample areas. (A) Indirectly affected soils (NAS), (B) directly affected soils (AS)

regulations, which suggested that the impacts of metallurgical activities most likely extended further into the soils than the maximum depth evaluated in this study $(1.0 \mathrm{~m})$.

Studies of soils from historical and modern amalgamation sites have reported $\mathrm{Hg}$ concentrations ranging from 0.13 to $542 \mathrm{mg} / \mathrm{kg}$. These wide $\mathrm{Hg}$ concentration variations are potentially associated with the production capacity, operation time, extent of amalgamation processing, and pollution mechanisms. Higher $\mathrm{Hg}$ concentrations were reported in soils that were impacted by direct mining waste deposits rather than by pollution through surface deposition of mining wastes or elemental $\mathrm{Hg}$ after aeolian dispersion (Lacerda and Salomons 1999). Thus, the high $\mathrm{Hg}$ concentrations in the soils at the sample sites in Cedral primarily resulted from the direct impacts of the amalgamation process and the mining waste deposition. However, the dispersion of $\mathrm{Hg}$ particles by wind and/or water transport also enriched the soils, and these dispersion mechanisms are influenced by climate and topography conditions (Navarro 2008, Santos-Francés et al. 2011). The potential contributions of dispersion as a pollution mechanism in the study area were observed at sample sites NAS- 1 and NAS-2, which were outside of the former amalgamation facilities. Thus, the $\mathrm{Hg}$ concentrations observed outside of the former amalgamation facilities were as higher as those observed inside of the former amalgamation facilities. Because the NAS- 1 and NAS- 2 sites were located on a floodplain, it was likely that the high $\mathrm{Hg}$ concentrations at these sites resulted from the accumulation of mining waste particles transported by discharge from upstream amalgamation facilities. Thus, the surface hydrological conditions at the site could play a role in controlling $\mathrm{Hg}$ dispersion during heavy seasonal rainfalls, which are distinctive in semiarid climates.

The Hg concentration profiles in the soil cores are presented in figure $\mathbf{3}$, and distinctive shapes and pronounced $\mathrm{Hg}$ concentration peaks are shown for sites NAS-3 (40-60 cm soil section), AS-1 (20-40 cm soil section) and AS-4 (40-60 cm soil section). The $\mathrm{Hg}$ concentrations varied less with depth at the other sampling sites. However, it was observed that the $\mathrm{Hg}$ concentrations slightly increased (NAS-2, AS-5 and AS-6) or decreased (NAS-1, NAS-3, AS-2 and AS-3) with increasing depth. The heterogeneity of the shapes of the $\mathrm{Hg}$ concentration profiles could be associated with soils cutting, filling and/or mixing in urbanized areas. The potential effects of urbanization on the compositions of surface and deep soils include the redistribution, homogenization and dilution of natural and anthropogenic elements (Meuser 2010).

The mean total $\mathrm{Hg}$ concentrations were significantly different (ANOVA, $95 \% \mathrm{CI}$ ) among the soil samples obtained at depths of $0-30 \mathrm{~cm}(62 \pm 16 \mathrm{mg} / \mathrm{kg})$, $30-60 \mathrm{~cm}(55 \pm 2 \mathrm{mg} / \mathrm{kg})$ and $60-100 \mathrm{~cm}(44 \pm 9 \mathrm{mg} / \mathrm{kg})$, indicating that the $\mathrm{Hg}$ concentration decreased with increasing depth. Thus, the distribution of $\mathrm{Hg}$ in the soil profiles suggested that physical and chemical $\mathrm{Hg}$ transport processes affected the downward movement of $\mathrm{Hg}$ through the soil profile. The mobilization of $\mathrm{Hg}$ in soils is controlled by several factors, including $\mathrm{Hg}$ speciation, soils physical and chemical properties and climatic conditions, such as precipitation and evaporation (Navarro 2008).

Authors such as Nacht and Gustin (2004) and Liang et al. (2014) indicated that adding small amounts of water to dry soils without reaching saturation, results in the release of $\mathrm{Hg}$ from the soils to the atmosphere. These emissions arose from the displacement of 
elemental $\mathrm{Hg}$ by water infiltrating the soil pores. In addition, $\mathrm{Hg}(\mathrm{II})$ in soil can be dissolved in the soil water pores. Subsequently, once the soil dries and the water begins to evaporate, the elemental $\mathrm{Hg}$ and $\mathrm{Hg}$ (II) in the water migrate to the surface by mass flow. Once $\mathrm{Hg}$ (II) is adsorbed to the surface of soil particles, it can be photo-reduced to elemental $\mathrm{Hg}$ and released to the atmosphere (Gustin et al. 2003). Because evaporation exceeds precipitation in Cedral, the process described above could be an important mechanism of Hg transport in soils. Therefore, the Hg solubility was assessed by using simulated conditions of rainwater contact to evaluate the net potential effects of all controlling factors on the aqueous transport of $\mathrm{Hg}$ in mining wastes and soils at Cedral.

\section{Concentration of soluble $\mathrm{Hg}$ in the mining wastes and soils}

In this study, the operationally soluble $\mathrm{Hg}$ is all that could pass through a $0.45 \mu \mathrm{m}$ diameter pore membrane as ions, molecules and bound to organic matter or colloidal mineral particles (Boszke et al. 2008).

The soluble $\mathrm{Hg}$ concentrations in the mining waste samples were significantly lower than the total $\mathrm{Hg}$ concentration, ranging from 0.009 to $0.32 \mathrm{mg} / \mathrm{kg}$. Thus, the solubility of $\mathrm{Hg}$ under simulated rainwater contact conditions varied from 0.007 to $0.54 \%$ of the total $\mathrm{Hg}$ found in the mining wastes. The latter in agreement with the soluble fraction of $\mathrm{Hg}$ $(0.01-0.22 \%)$ in the samples from the El Caballo and Jesús María dumps reported by Morton-Bermea et al. (2015). The data from other historical and modern amalgamation sites are consistent with the results from Cedral, which indicated that the aqueous solubility of $\mathrm{Hg}$ is low in amalgamation mining wastes (Lacerda and Salomons 1999). The concentrations of soluble $\mathrm{Hg}$ indicate that the transport of $\mathrm{Hg}$ resulting from $\mathrm{Hg}$ solubilization in rainwater is negligible during rainfall events in Cedral.

The differences in the soluble $\mathrm{Hg}$ concentrations among the mining waste sample areas are shown in figure 4. According to the different characteristics among the mining waste sample sites (Table II), the highest soluble $\mathrm{Hg}$ concentration was associated to the reprocessed waste. Therefore, reprocessed amalgamation tailings from the lixiviation pond site WEC-2 had the highest concentrations of soluble $\mathrm{Hg}$ at the surface $(0.10 \mathrm{mg} / \mathrm{kg})$ and at a depth of $40-50 \mathrm{~cm}$ $(0.32 \mathrm{mg} / \mathrm{kg})$. Notably, the concentrations of soluble $\mathrm{Hg}$ at non-reprocessed amalgamation tailings were near the detection limit of $0.004 \mathrm{mg} / \mathrm{kg}$. In these samples, it was suspected that elemental $\mathrm{Hg}$ is the main chemical species responsible for the low $\mathrm{Hg}$
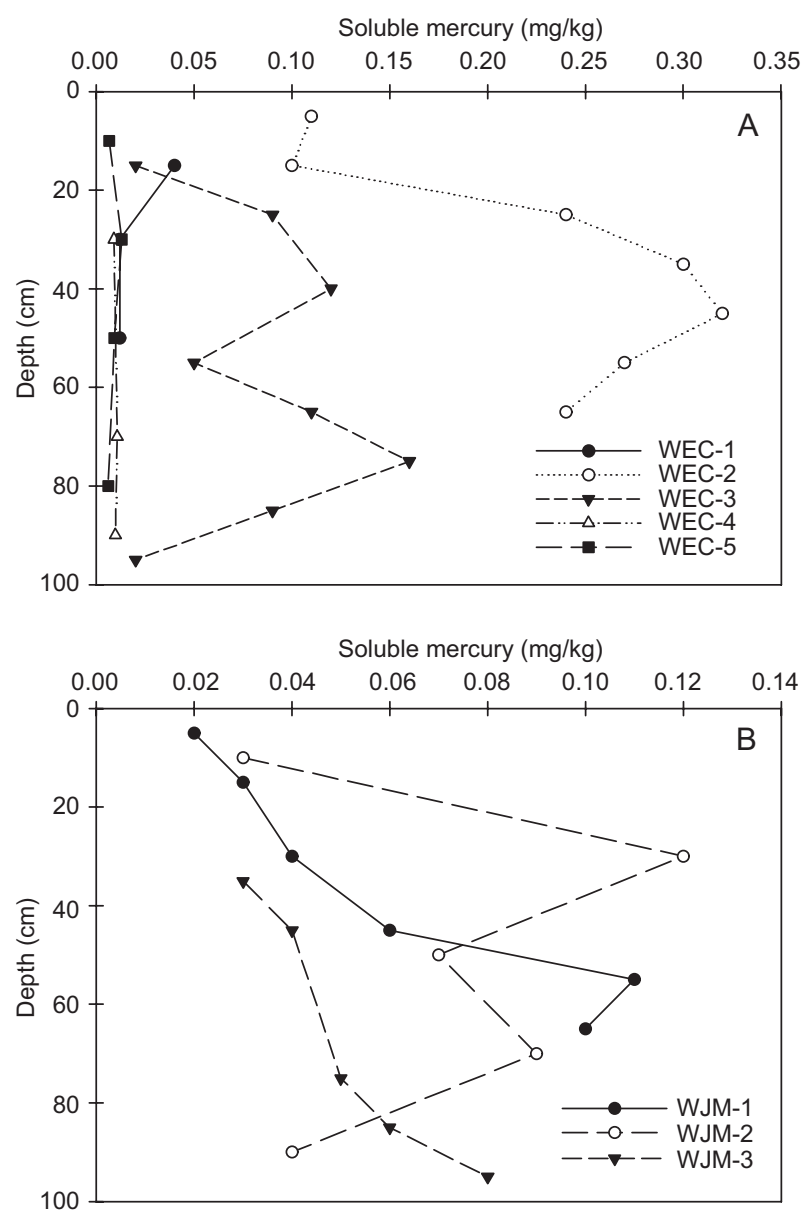

Fig. 4. Variations in the soluble mercury concentrations (mg/ $\mathrm{kg}$ ) with depth $(\mathrm{cm})$ at the mining wastes sample areas. (A) El Caballo wastes (WEC), (B) Jesús María wastes (WJM)

solubility in non-reprocessed mining wastes from Cedral. Elemental $\mathrm{Hg}$ has been reported as a major chemical species that causes low $\mathrm{Hg}$ solubility in amalgamation mining wastes (Bloom et al. 2003). In contrast, the WEC-2 site exemplified conditions of reprocessed tailings at the stage of lixiviation with $\mathrm{CaS}_{2} \mathrm{O}_{3}$ because it corresponded to the mining waste content in one pond from the El Caballo reprocessing plant. Therefore, the relatively higher concentrations of soluble $\mathrm{Hg}$ could be caused by the occurrence of soluble $\mathrm{Hg}$ compounds that were formed during the leaching of amalgamation residues (Ogura et al. 2003). The increase in the concentration of soluble $\mathrm{Hg}$ due to reprocessing was also observed in samples from reprocessed tailing dumps (WEC-3, WJM-1, WJM-2 and WJM-3).

The $\mathrm{Hg}$ solubility found in the reprocessed mining wastes from Cedral likely resulted from the prevalence of $\mathrm{Hg}$ sulfide $(\mathrm{HgS})$, which was the main $\mathrm{Hg}$ 
species according to a previous study of the same reprocessed tailings from Cedral (Bayer 2013).

The depth-dependent variations in the concentrations of soluble $\mathrm{Hg}$ in the mining wastes showed clear differences among the sample sites (Fig. 4). Thus, the sample areas with lower soluble $\mathrm{Hg}$ concentrations (WEC-1, WEC-4 and WEC-5) showed low variation with depth. This trend was also observed in WJM-3, except for a small increase in the soluble $\mathrm{Hg}$ concentrations in the deeper sections. The samples from sites WEC-2, WEC-3, WJM-1 and WJM-2 had a noticeable peak of soluble $\mathrm{Hg}$ concentrations in the middle and deeper sections of the mining waste profiles.

The soluble $\mathrm{Hg}$ concentrations in the soils varied from 0.003 to $0.04 \mathrm{mg} / \mathrm{kg}$ (Fig. 5) and were lower than the soluble $\mathrm{Hg}$ concentrations observed in the mining waste samples. Soluble $\mathrm{Hg}$ represented < $0.03 \%$ of the total $\mathrm{Hg}$ in the soil samples, which was consistent with data obtained from studies of soils
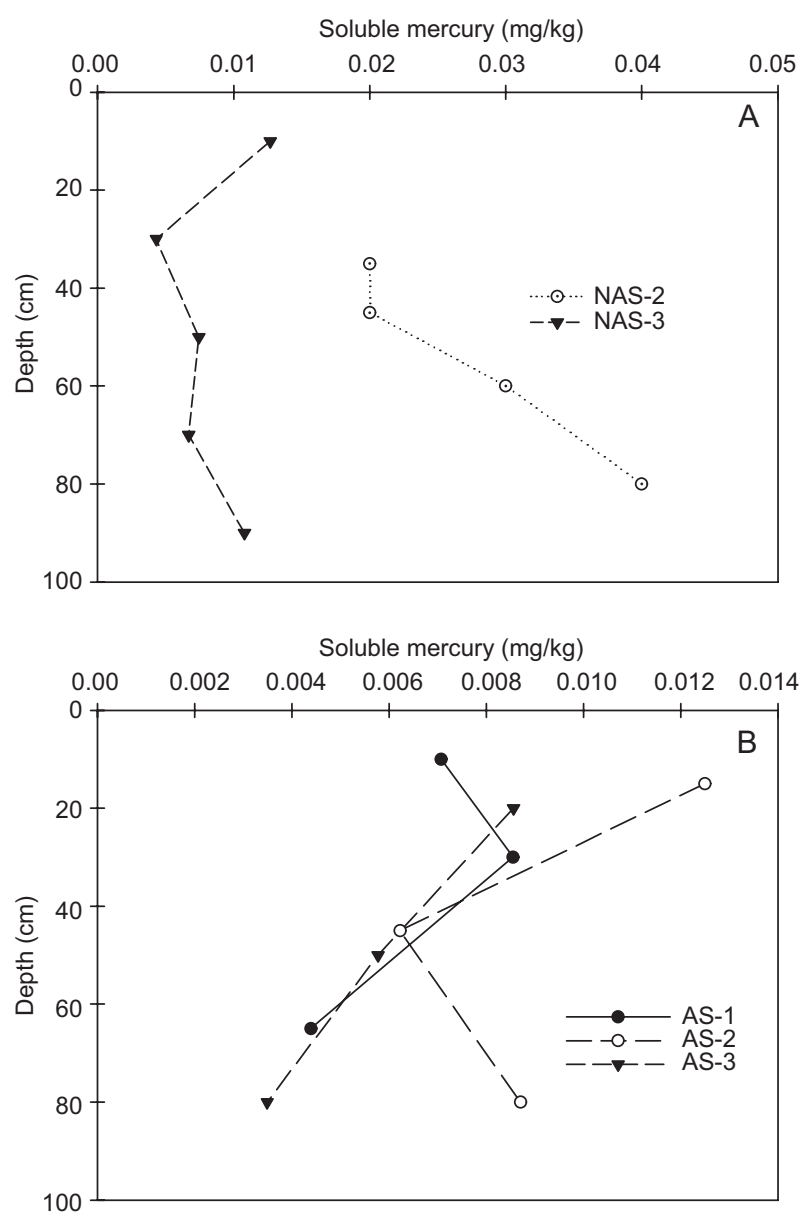

Fig. 5. Variations in the soluble mercury concentrations $(\mathrm{mg} / \mathrm{kg})$ with depth $(\mathrm{cm})$ at the soil sample areas. (A) Indirectly affected soils (NAS), (B) directly affected soils (AS) near former amalgamation areas with mean soluble $\mathrm{Hg}$ concentrations of only $0.05 \%$ of the total $\mathrm{Hg}$ concentration (Santos-Francés et al. 2011). However, the soluble $\mathrm{Hg}$ fraction was lower than the one reported previously $(0.37-0.68 \%)$ for two soil samples from Cedral (Morton-Bermea et al. 2015).

The soluble $\mathrm{Hg}$ concentrations among the soil sample sites were not high enough to detect significant differences (ANOVA, $95 \% \mathrm{CI}$ ). Nonetheless, as shown in figure $\mathbf{5 A}$, the soluble $\mathrm{Hg}$ concentrations in the NAS-2 soils were notably higher than those in the soils from the other sample sites and increased with depth from 0.02 to $0.04 \mathrm{mg} / \mathrm{kg}$. Therefore the low solubility of $\mathrm{Hg}$ in the mining waste and soil samples under simulated rainwater contact conditions indicated that aqueous transport was a minor contributor to the vertical migration governed by soluble chemical $\mathrm{Hg}$ species. Thus, colloidal transport could play a major role in the downward migration of $\mathrm{Hg}$ in soils (Navarro 2008).

\section{Bioaccessible $\mathrm{Hg}$ in the mining waste and soil samples}

A previous study has shown that children from Cedral are exposed to $\mathrm{Hg}$ (Morton-Bermea et al. 2015). Taking into account that seafood is not an important dietary component in Cedral, the bioaccessible $\mathrm{Hg}$ concentrations were determined in order to evaluate if the accidental ingestion of mining wastes and polluted soil particles could be a major exposure route.

The concentrations of bioaccessible $\mathrm{Hg}$ in the mining waste samples are expressed in $\mathrm{mg}$ of bioaccessible $\mathrm{Hg}$ per $\mathrm{kg}$ of mining wastes, and range from 0.1 to $60 \mathrm{mg} / \mathrm{kg}$ (Fig. 6). These values were lower than the total $\mathrm{Hg}$ concentrations (Fig. 2) but higher than the soluble Hg concentrations (Fig. 4). The latter might be due to more acidic conditions, higher $\mathrm{Cl}^{-}$concentrations and the presence of the organic functional groups of glycine in the extraction solutions (Ravichandran 2004, Jing et al. 2007).

The mining waste sample area WEC-2 had the highest values of bioaccessible $\mathrm{Hg}$, ranging from 9 to $60 \mathrm{mg} / \mathrm{kg}$. In contrast, the other sample areas had lower bioaccessible $\mathrm{Hg}$ concentrations that ranged from 0.1 to $22 \mathrm{mg} / \mathrm{kg}$. The bioaccessibility of $\mathrm{Hg}$ is primarily controlled by its chemical speciation, which depends on the nature of the primary source and on the physical and chemical properties of the polluted soils (Zagury et al. 2009). The bioaccessible $\mathrm{Hg}$ concentrations at WEC-2 sample site represent less than $10 \%$ of the total $\mathrm{Hg}$ concentration. The concentrations of bioaccessible $\mathrm{Hg}$ in the WEC-1, WEC-4 and WEC-5 non-reprocessed mining waste sites were less than $1 \%$ of the total $\mathrm{Hg}$ concentration, 

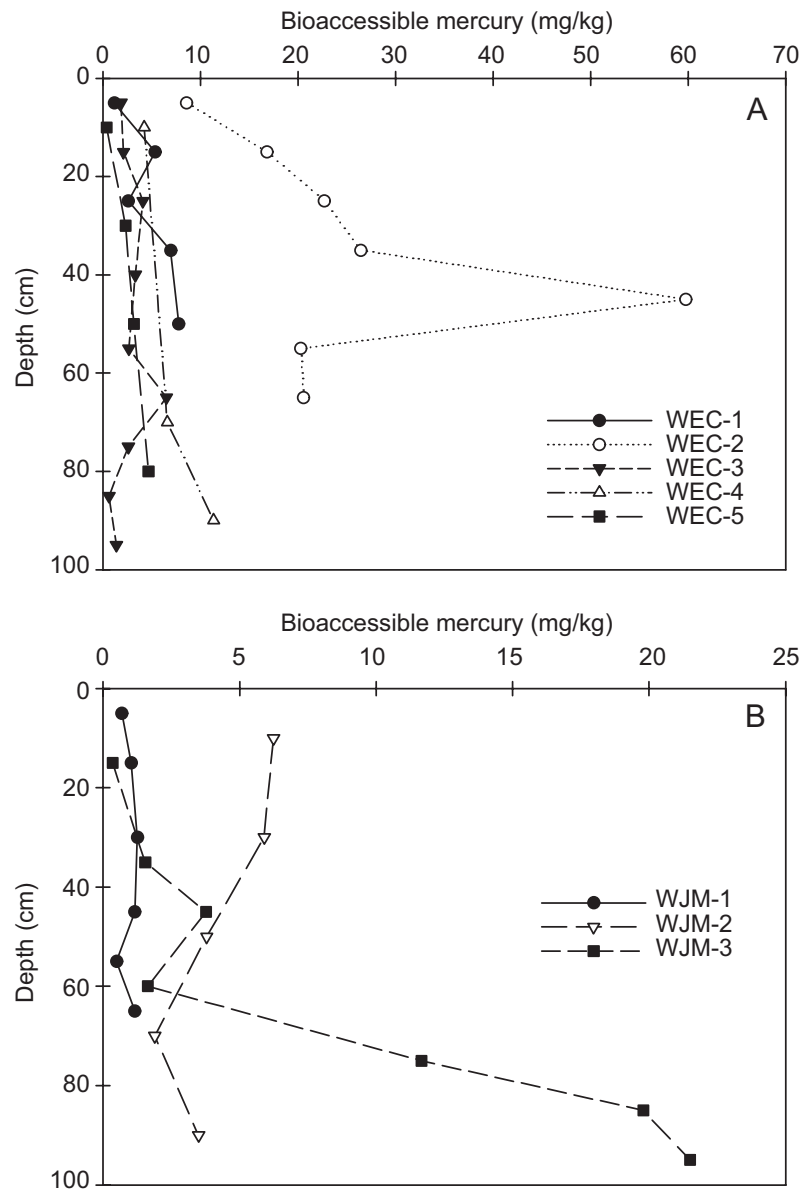

Fig. 6. Variations in the bioaccessible mercury concentrations $(\mathrm{mg} / \mathrm{kg})$ with depth $(\mathrm{cm})$ in the mining wastes sample areas. (A) El Caballo wastes (WEC), (B) Jesús María wastes (WJM)

as clearly observed at the WEC-1 sample site, which had the highest total $\mathrm{Hg}$ concentration. Thus, these results are supported by the predominant occurrence of $\mathrm{HgS}$ in reprocessed tailings (Bayer 2013), and they may be explained because elemental $\mathrm{Hg}$ is the primary chemical species in non-reprocessed mining wastes, since these $\mathrm{Hg}$ species present low bioaccessibilities in soils and mining wastes (Davis et al. 1997, Zagury et al. 2009).

Despite the limited bioaccessibility of $\mathrm{Hg}$, the highest bioaccessible concentration of $\mathrm{Hg}$ observed in this study $(60 \mathrm{mg} / \mathrm{kg})$, exceeded the health-risk-based Mexican regulation of $23 \mathrm{mg} / \mathrm{kg}$ for residential soils by nearly three times, which suggests that ingestion of mining waste particles could be a major exposure pathway for $\mathrm{Hg}$ in the studied area.

Regarding the variations in the bioaccessible $\mathrm{Hg}$ concentrations with mining waste depth in the WEC-2 sample area, an important peak in the $\mathrm{Hg}$
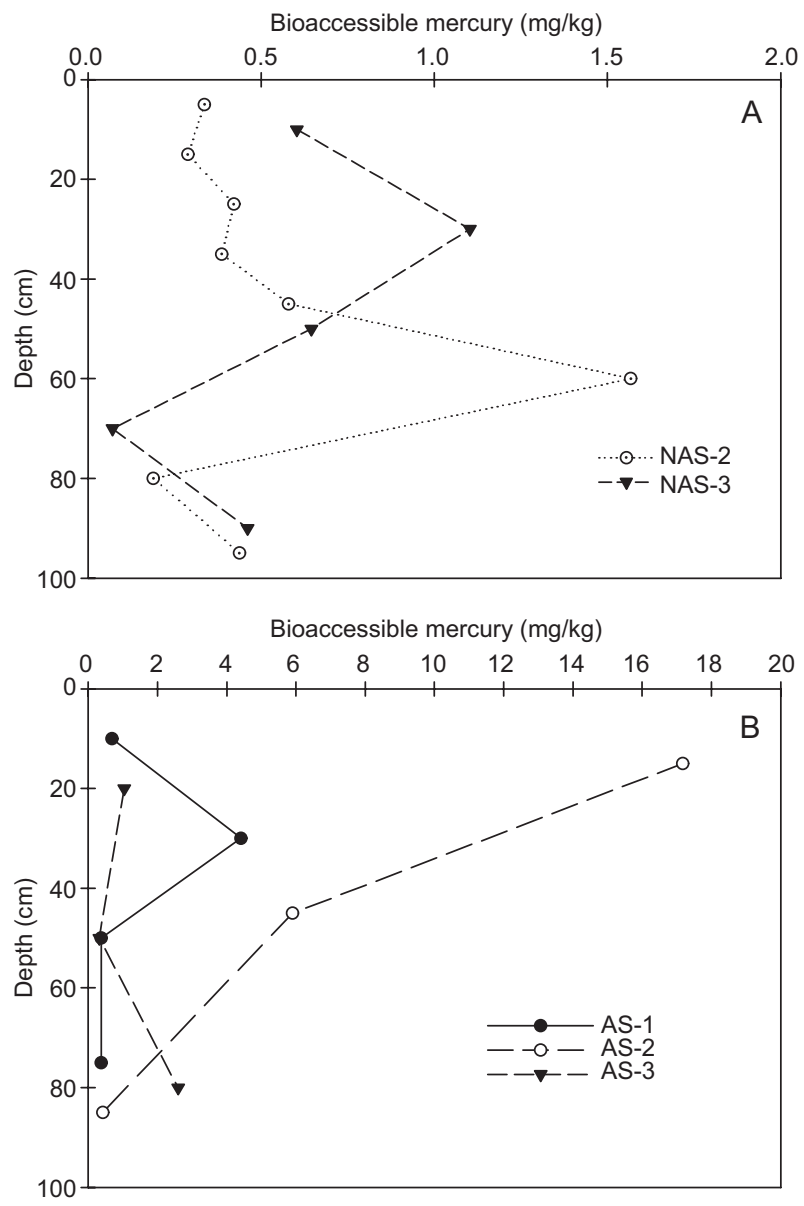

Fig. 7. Variations in the bioaccessible mercury concentrations $(\mathrm{mg} / \mathrm{kg})$ with depth $(\mathrm{cm})$ at the soil sample areas. (A) Indirectly affected soils (NAS), (B) directly affected soils (AS)

concentration was observed, with concentrations of $26 \mathrm{mg} / \mathrm{kg}$ at $40-50 \mathrm{~cm}$ to $60 \mathrm{mg} / \mathrm{kg}$ at $50-60 \mathrm{~cm}$, which coincided with the higher total and soluble $\mathrm{Hg}$ concentrations at the same sample site and in WJM-3 sample site. A notable increase in the concentration of bioaccessible $\mathrm{Hg}$ occurred with the bioaccessible $\mathrm{Hg}$ concentration reaching $22 \mathrm{mg} / \mathrm{kg}$ in the deepest sampled section $(90-100 \mathrm{~cm})$. Thus, the vertical distributions of bioaccessible $\mathrm{Hg}$ at the WEC-2 and WJM-3 mining waste sample sites were primarily controlled by the total $\mathrm{Hg}$ concentration. The shapes of the total, soluble and bioaccessible $\mathrm{Hg}$ profiles were similar for this sample area, which indicated a homogenous distribution of chemical $\mathrm{Hg}$ species throughout the sampled mining waste profile.

The bioaccessible $\mathrm{Hg}$ concentrations in soils ranged from 0.1 to $17 \mathrm{mg} / \mathrm{kg}$ and were notably different among the sample areas (Fig. 7). The samples from the NAS-2, NAS-3 and AS-3 areas had lower 
bioaccessible $\mathrm{Hg}$ concentrations of 0.1 to $3 \mathrm{mg} / \mathrm{kg}$ that varied slightly with depth. By contrast, site AS-1 had a significant peak of the bioaccessible $\mathrm{Hg}$ concentration of up to $4 \mathrm{mg} / \mathrm{kg}$ at a depth of $20-40 \mathrm{~cm}$, and the AS-2 sample area had a distinctive bioaccessible $\mathrm{Hg}$ concentration profile that clearly decreased from $17 \mathrm{mg} / \mathrm{kg}$ at the surface to $0.4 \mathrm{mg} / \mathrm{kg}$ in the deeper sections. Similar patterns in the total (Fig. 3) and bioaccessible $\mathrm{Hg}$ (Fig. 7) concentrations were observed at the AS-1 and AS-2 sample sites, which indicated that the bioaccessibility of $\mathrm{Hg}$ were homogenous throughout the studied soil profiles.

\section{CONCLUSIONS}

This study confirmed the existence of $\mathrm{Hg}$ sources and soil pollution due to historical and recent metallurgical activities at the study site.

The most affected soils were those on which amalgamation activities were conducted. Besides, the $\mathrm{Hg}$ concentrations in soils determined at areas outside of the former amalgamation facilities, indicated that $\mathrm{Hg}$ was dispersed in the surrounding areas.

The high $\mathrm{Hg}$ concentrations observed at soil depths of up to $1.0 \mathrm{~m}$ indicated the severe impacts of metallurgical activities in these soils years after metallurgical activities were stopped, which highlights the importance of evaluating this site with more detail.

The soluble $\mathrm{Hg}$ concentration indicated that during a rainfall event the aqueous transport of dissolved $\mathrm{Hg}$ at the sample sites is negligible. In contrast, the observed bioaccessible $\mathrm{Hg}$ concentrations confirmed that humans could be exposed to $\mathrm{Hg}$ at these sites by accidentally ingesting mining wastes and soil particles.

The soluble and bioaccessible $\mathrm{Hg}$ concentrations in the non-reprocessed and reprocessed mining wastes indicated that the water solubility and bioaccessibility of $\mathrm{Hg}$ increased after reprocessing. Additional studies should be conducted to understand the effect of reprocessing on $\mathrm{Hg}$ speciation at this site.

A risk, not considered here, should be the possible atmospheric emissions of gaseous $\mathrm{Hg}$ from these wastes or contaminated soils. An assessment of this possibility should be important to evaluate the exposure of vapor $\mathrm{Hg}$ through inhalation in order to delimitate the areas with higher potential risks.

\section{ACKNOWLEDGMENTS}

Adriana Leura Vicencio is grateful for the doctoral fellowship provided by the Consejo Nacional de Ciencia y Tecnología (CONACyT). The authors gratefully acknowledge Isidro Montes and Daniel Pacheco for their fieldwork support and Izanami López for assisting with the chemical analyses. The authors wish to thank the anonymous reviewers for their valuable comments and suggestions to improve the quality of the manuscript.

\section{REFERENCES}

Aguirre J. (1878). Plano del Cedral [online] http://w2.siap. sagarpa.gob.mx/mapoteca/mapas/4341-CGE-7242-A. jpg 23/03/2013

ASTM (2004). ASTM Designation: D 3987-85, Standard test method for shake extraction of solid waste with water. American Society for Testing and Materials International. Standard. West Conshohocken, PA, USA, 4 pp.

Ávalos-Lozano J. A., Medellín-Milán P., Aguilar-Robledo M. and Nieto-Caraveo L. M. (2007). Amenaza previsible. Lecciones de historia sobre la aplicabilidad del principio precautorio. Trayectorias 9 (24), 31-44.

Bargalló M. (1969). La amalgamación de los minerales de plata. Compañía Fundidora de Fierro y Acero de Monterrey. Mexico City, Mexico, $601 \mathrm{pp}$.

Bayer F. M. (2013). Quecksilberspeziation von Bergbaurüyckständen aus Fresnillo und Cedral, Mexiko. Master Thesis. Karlsruhe Institute of Technology. Karlsruhe, Germany, 75 pp.

Bloom N. S., Preus E., Katon J. and Hiltner M. (2003). Selective extractions to assess the biogeochemically relevant fractionation of inorganic mercury in sediments and soils. Anal. Chim. Acta 479 (2), 233-248. DOI: $10.1016 / \mathrm{S} 0003-2670(02) 01550-7$

Boszke L., Kowalski A., Astel A., Baranski A., Gworek B. and Siepak J. (2008). Mercury mobility and bioavailability in soil from contaminated area. Environ. Geol. 55 (5), 1075-1087. DOI: 10.1007/s00254-007-1056-4

Camargo J. A. (2002). Contribution of Spanish-American silver mines (1570-1820) to the present high mercury concentrations in the global environment: a review. Chemosphere 48 (1), 51-57.

DOI: $10.1016 / \mathrm{S} 0045-6535(02) 00047-4$

CEC (2013). An assessment of primary and secondary mercury supplies in Mexico. Commission for Environmental Cooperation. Project report. Montreal, Quebec, Canada, 102 pp.

Chiprés J. A., Salinas J. C., Castro-Larragoitia J., and Monroy M. (2008). Geochemical mapping of major and trace elements in soils from the Altiplano Potosino, Mexico: A multiscale comparison. Geochem-Explor. Environment A. 8 (3-4), 279-290.

DOI: $10.1144 / 1467-7873 / 08-181$ 
CRM (1992). Monografía geológico-minera del estado de San Luis Potosí. Consejo de Recursos Minerales. Monograph. Pachuca, Hidalgo, Mexico, 218 pp.

Davis A., Bloom N. S. and Hee S. S. Q. (1997). The environmental geochemistry and bioaccessibility of mercury in soils and sediments: a review. Risk Anal. 17 (5), 557-569.

DOI: $10.1111 / \mathrm{j} .1539-6924.1997 . t b 00897 . x$

Ebinghaus R. T. (1999). Natural and anthropogenic mercury sources and their impact on the air-surface exchange of mercury on regional and global scales. In: Mercury contaminated sites. Characterization, risk assessment and remediation (R. Ebinghaus, R. Turner, L. D. Lacerda, O. Vasiliev and W. Salomons, Eds.). Springer, Heidelberg, Germany, pp. 3-50.

DOI: 10.1007/978-3-662-03754-6_1

Gustin M. S., Coolbaugh M. F., Engle M. A., Fitzgerald B. C., Keislar R. E., Lindberg S. E., Nacht D. M., Quashnick J., Rytuba J. J., Sladek C., Zhang H. and Zehner R. E. (2003). Atmospheric mercury emissions from mine wastes and surrounding geologically enriched terrains. Environ. Geol. 43 (3), 339-351.

Hornelas F. A. (1905). Plano del Cedral [online]. http:// w2.siap.sagarpa.gob.mx/mapoteca/mapas/2837-OYB7242-B.jpg 23/03/2013.

Hylander L. D. and Meili M. (2003). 500 years of mercury production: global annual inventory by region until 2000 and associated emissions. Sci. Total Environ. 304 (1-3), 13-27. DOI: 10.1016/S0048-9697(02)00553-3

INEGI (1972). Carta edafológica Cedral F-14-A-14 Esc. 1:50 000. Instituto Nacional de Estadística y Geografía [online]. http://internet.contenidos. inegi.org.mx/contenidos/Productos/prod_serv/contenidos/espanol/bvinegi/productos/geografia/tematicas/Edafologia_hist/1_50_000/702825660444.pdf 25/06/2012.

INEGI (2009). Prontuario de información geográfica municipal de los Estados Unidos Mexicanos. Cedral, San Luis Potosí. Clave geoestadística 24007. Instituto Nacional de Estadística y Geográfica. Summary. Aguascalientes, Aguascalientes, Mexico, 9 pp.

INEGI (2010). Censo de población y vivienda 2010. Principales resultados por localidad (ITER) [online]. http:// www.inegi.org.mx/sistemas/consulta_resultados/ iter2010.aspx?c=27329\&s=est 08/10/2014.

Jing Y. D., He Z. L. and Yang X. E. (2007). Effects of pH, organic acids, and competitive cations on mercury desorption in soils. Chemosphere 69 (10), 1662-1669. DOI: $10.1016 /$ j.chemosphere.2007.05.033

Johnson D. A. and Whittle K. (1999). The chemistry of the Hispanic-American amalgamation process. J. Chem. Soc., Dalton Trans. (23), 4239-4243.

DOI: $10.1039 /$ A905612B
Kabata-Pendias A. (2011). Trace elements in soils and plants. 4th ed. CRC Press. Boca Raton, USA, 520 pp.

Kelley M. E., Brauning S. E., Schoof R. A. and Ruby M. V. (2002). Assessing oral bioavailability of metals in soil. Battelle Press. Columbus, USA, 124 pp.

Lacerda L. D. (1997). Global mercury emissions from gold and silver mining. Water Air Soil Pollut. 97 (3), 209-221. DOI: 10.1007/BF02407459

Lacerda L. D. and Salomons W. (1999). Mercury contamination from the New World gold and silver mine tailings. In: Mercury contaminated sites. Characterization, risk assessment and remediation (R. Ebinghaus, R. Turner, L. D. Lacerda, O. Vasiliev and W. Salomons, Eds.). Springer, Heidelberg, Germany, pp. 73-87.

DOI: 10.1007/978-3-662-03754-6 3

Lang M. F. (1999). Azoguería y Amalgamación. Una apreciación de sus esencias químico-metalúrgicas, sus mejoras y su valor metalúrgico en el marco científico de la época colonial. Llull 22 (45), 655-673

Liang P., Zhang C., Yang Y. and Wang D. (2014). A simulation study of mercury release from soils in wet-dry rotation environment. J. Environ. Sci. 26 (7), 14451452. DOI: $10.1016 /$ j.jes.2014.05.010

Meuser H. (2010). Contaminated urban soils. Springer, Dordrecht, Netherlands. 318 pp.

DOI: $10.1007 / 978-90-481-9328-8$

Moore C. W. and Castro M. S. (2012). Investigation of factors affecting gaseous mercury concentrations in soils. Sci. Total Environ. 419, 136-143.

DOI: 10.1016/j.scitotenv.2011.12.068

Morton-Bermea O., Jiménez-Galicia R. G., Castro-Larragoitia J., Hernández-Álvarez E., Pérez-Rodríguez R., García-Arreola M. E., Gavilán-García I. and Segovia N. (2015). Anthropogenic impact of the use of $\mathrm{Hg}$ in mining activities in Cedral S.L.P. Mexico. Environ. Earth Sci. 74 (2), 1161-1168. DOI: $10.1007 / \mathrm{s} 12665-015-4102-7$

Nacht D. M. and Gustin M. S. (2004). Mercury emissions from background and altered geologic units throughout Nevada. Water Air Soil Pollut. 151 (1), 179-193.

DOI: 10.1023/B:WATE.0000009907.49577.a8

Navarro A. (2008). Review of characteristics of mercury speciation and mobility from areas of mercury mining in semi-arid environments. Rev. Environ. Sci. Bio. 7 (4), 287-306. DOI: 10.1007/s11157-008-9139-6

Nriagu J. O. (1994). Mercury pollution from the past mining of gold and silver in the Americas. Sci. Total Environ. 149 (3), 167-181. DOI: 10.1016/0048-9697(94)90177-5

Ogura T., Ramírez-Ortiz J., Arroyo-Villaseñor Z. M., Hernández-Martínez S., Palafox-Hernandéz J. P., García de Alba L. H. and Quintus F. (2003). Zacatecas (Mexico) companies extract $\mathrm{Hg}$ from surface soil 
contaminated by ancient mining industries. Water Air Soil Pollut. 148 (1), 167-177.

DOI: $10.1023 / \mathrm{A}: 1025497726115$

Pansu M. and Gautheyrou J. (2006). Handbook of soil analysis. Mineralogical, organic and inorganic methods. Springer, Heidelberg, Germany. 993 pp.

DOI: 10.1007/978-3-540-31211-6

Ramos-Arroyo Y. R., Prol-Ledesma R. M. and SiebeGrabach C. D. (2004). Características geológicas y mineralógicas e historia de extracción del Distrito de Guanajuato, México. Posibles escenarios geoquímicos para los residuos mineros. Rev. Mex. Cienc. Geol. 21 (2), 268-284.

Ravichandran M. (2004). Interactions between mercury and dissolved organic matter-a review. Chemosphere 55 (3), 319-331.

DOI: 10.1016/j.chemosphere.2003.11.011

Santos-Francés F., García-Sánchez A., Alonso-Rojo P., Contreras F. and Adams M. (2011). Distribution and mobility of mercury in soils of a gold mining region, Cuyuni river basin, Venezuela. J. Environ. Manage. 92 (4), 1268-1276. DOI: 10.1016/j.jenvman.2010.12.003 SEMARNAT (2004). Norma Oficial Mexicana NOM147-SEMARNAT/SSA1-2004. Que establece criterios para determinar las concentraciones de remediación de suelos contaminados por arsénico, bario, berilio, cadmio, cromo hexavalente, mercurio, níquel, plata, plomo, selenio, talio y/o vanadio. Secretaría de Medio Ambiente y Recursos Naturales. Diario Oficial de la Federación. 2 de marzo de 2007.

SEMARNAT (2009). Norma Oficial Mexicana NOM157-SEMARNAT-2009. Que establece los elementos y procedimientos para instrumentar planes de manejo de residuos mineros. Secretaría de Medio Ambiente y Recursos Naturales. Diario Oficial de la Federación. 30 de agosto de 2011.
SGM (2013). Carta geológico-minera Cedral F14-A14. [online].http://mapserver.sgm.gob.mx/Cartas_Online/ geologia/1454_F14-A14_GM.pdf 28/10/2016

Slowey A. J., Rytuba J. J. and Brown G. E. (2005). Speciation of mercury and mode of transport from placer gold mine tailings. Environ. Sci. Technol. 39 (6), 1547-1554. DOI: $10.1021 / \mathrm{es} 049113 \mathrm{z}$

SMN (2015). Normales climatológicas. Periodo 19512010. Estación 24007 Cedral [online]. http://smn. cna.gob.mx/tools/RESOURCES/Normales5110/ NORMAL24007.TXT 30/11/2015.

Song X. and Van Heyst B. (2005). Volatilization of mercury from soils in response to simulated precipitation. Atmos. Environ. 39 (39), 7494-7505.

DOI: 10.1016/j.atmosenv.2005.07.064

USEPA (2007a). Method 3051A. Microwave assisted acid digestion of sediments, sludges, soils and oils. United States Environmental Protection Agency. Method. Washington D.C., USA, $30 \mathrm{pp}$.

USEPA (2007b). OSWER 9285.7-77. Estimation of relative bioavailability of lead in soil and soil-like materials using in vivo and in vitro methods. United States United States Environmental Protection Agency. Memorandum. Washington D.C., USA, 24 pp.

USEPA (2014). Regional screening levels (RSLs) - Generic tables (May 2016). United States Environmental Protection Agency [online]. https://www.epa.gov/ risk/regional-screening-levels-rsls-generic-tablesmay-2016 24/10/2016.

Zagury G. J., Bedeaux C. and Welfringer B. (2009). Influence of mercury speciation and fractionation on bioaccessibility in soils. Arch. Environ. Con. Tox. 56 (3), 371-379. DOI: 10.1007/s00244-008-9205-7 